OPEN ACCESS

Edited by:

Mei Jiang,

Guangzhou Institute of Respiratory

Disease, China

Reviewed by:

Stephen J. Fowler,

The University of Manchester,

United Kingdom

Min Wu,

University of North Dakota,

United States

*Correspondence:

Manxiang Li

manxiangli@hotmail.com

Specialty section:

This article was submitted to

Respiratory Pharmacology,

a section of the journal

Frontiers in Pharmacology

Received: 27 October 2018

Accepted: 11 March 2019

Published: 28 March 2019

Citation:

Xie X, Lyu J, Hussain T and Li M (2019) Drug Prevention and Control of Ventilator-Associated Pneumonia. Front. Pharmacol. 10:298. doi: 10.3389/fphar.2019.00298

\section{Drug Prevention and Control of Ventilator-Associated Pneumonia}

\author{
Xinming Xie' ${ }^{1}$, Jun Lyu' ${ }^{2}$, Tafseel Hussain ${ }^{1}$ and Manxiang $L i^{1 *}$ \\ ' Department of Respiratory and Critical Care Medicine, The First Affiliated Hospital, Xi'an Jiaotong University, Xi'an, China, \\ ${ }^{2}$ Clinical Research Center, The First Affiliated Hospital, Xi'an Jiaotong University, Xi'an, China
}

Ventilator-associated pneumonia (VAP) is one of the most prevalent and serious complications of mechanical ventilation, which is considered a common nosocomial infection in critically ill patients. There are some great options for the prevention of VAP: (i) minimize ventilator exposure; (ii) intensive oral care; (iii) aspiration of subglottic secretions; (iv) maintain optimal positioning and encourage mobility; and (v) prophylactic probiotics. Furthermore, clinical management of VAP depends on appropriate antimicrobial therapy, which needs to be selected based on individual patient factors, such as previous antibacterial therapy, history of hospitalization or mechanical ventilation, and bacterial pathogens and antibiotic resistance patterns. In fact, antibiotic resistance has exponentially increased over the last decade, and the isolation of a multidrug-resistant (MDR) pathogen has been identified as an independent predictor of inadequate initial antibiotic therapy and which is significantly associated with increased mortality. Multiple attempts were used in the treatment of VAP, such as novel antibacterial agents, inhaled antibiotics and monoclonal antibodies. In this review, we summarize the current therapeutic options for the prevention and treatment of VAP, aiming to better management of VAP in clinical practice.

Keywords: antibiotics, monoclonal antibodies, probiotics, chlorhexidine, ventilator-associated pneumonia

\section{INTRODUCTION}

Ventilator-associated pneumonia (VAP) is believed to be the most commonly acquired infection in the intensive care unit (ICU) and is associated with high morbidity and mortality rates (Timsit et al., 2017a; Vandana Kalwaje and Rello, 2018). The incidence of VAP ranges from 10 to $25 \%$ of all ICU patients, the VAP-related mortality rate is between 24 and $76 \%$, which is 6-21 times higher in the intubated patients (Dasgupta et al., 2015). VAP usually occurs $48-72 \mathrm{~h}$ after mechanical ventilation and is related to the increased incidence of multidrug-resistant (MDR) infections, prolonged mechanical ventilation, increased antibiotic usage, and patient stay in the hospital (Charles et al., 2014). Although prevention efforts may reduce the frequency of these infections, unfortunately, only a few preventive strategies have been demonstrated to be effective in managing VAP, while many others should be further evaluated in large randomized trials before becoming the clinical recommendations (Li Bassi et al., 2017). In addition, it's very challenging to make the correct diagnosis of VAP in the clinical setting in the absence of a gold standard (Tejerina et al., 2010; Nair and Niederman, 2015; Timsit et al., 2017a).

A prevention policy aiming to reduce VAP remains an important element of the management for patients admitted to ICUs and requiring mechanical ventilation. The current preventive 
strategies for VAP are mainly directed at colonization and aspiration modification, such as avoiding intubation (Carron et al., 2013), oral care (Nicolosi et al., 2014), assessing for early weaning and mobility (Balas et al., 2014; Klompas et al., 2015), and prophylactic probiotics (Wong et al., 2015). The empiric treatment strategies of VAP should be informed by the local distribution of pathogens and their antimicrobial susceptibilities, because the pathogens responsible for VAP and the drugresistance situation are varying from region to region (Weber et al., 2007; Chung et al., 2011; Mathai et al., 2016; Awad et al., 2018). VAP is commonly caused by Pseudomonas aeruginosa, Klebsiella pneumonia, and Acinetobacter baumannii globally. It is important that the antimicrobial therapy be right in the first time in VAP patients, because the pathogens associated with inappropriate initial therapy are usually antibiotic-resistant strains of these pathogens, so patients at high risk of infection with these organisms initially needed to receive a combination of agents providing a very broad spectrum of coverage (Weiner et al., 2016; Rhodes et al., 2018). This review aims to summarize the available knowledge on drug prevention and control of VAP, taking profit from the recommendations of several health organization such as the American Thoracic Society with the Infectious Disease Society of America (Kalil et al., 2016), the Centers for Disease Control and Prevention (CDC) (Tablan et al., 2004), the European Task Force on VAP (Torres and Carlet, 2001), the Society for Healthcare Epidemiology of America, and the Institute for Healthcare Improvement (Klompas et al., 2014), as well as the recently major guidelines for the management of VAP (Kalil et al., 2016; Timsit et al., 2017a; Torres et al., 2017), and we hope that our clinicians know more about the initial therapies and treatment strategies of VAP, and we can investigate and focus on the management of the disease in future.

\section{DEFINITION AND DIAGNOSIS OF VAP}

Currently, there is no gold standard and valid definition for VAP, even the most widely used VAP criteria and definitions are neither sensitive nor specific. From 2013, the ventilatorassociated event (VAE) was established by CDC based on a novel and multi-tiered algorithm, including definitions for a ventilator-associated condition (VAC), infection-related ventilator-associated complication (IVAC), and possible or probable VAP (PVAP). These definitions were developed in order to better capture infectious and non-infectious events in patients receiving mechanical ventilation (Magill et al., 2013). Unfortunately for the bedside practitioner, the new CDC definition for VAP has been found to have a sensitivity as low as $37 \%$ with a negative predictive value of only $84 \%$, suggesting that VAE algorithm might not be intended for use in the clinical management of patients. In 2016, CDC reported a module about the definition of VAP is pneumonia that arises at least $48 \mathrm{~h}$ after endotracheal intubation (Erb et al., 2016). As shown in Figure 1, despite lacking a gold standard definition for VAP, they are still based on a combination of radiographic, laboratory, and clinical findings. Clinical suspicion of VAP in a patient is the initial part of the diagnosis, and the recommended standard

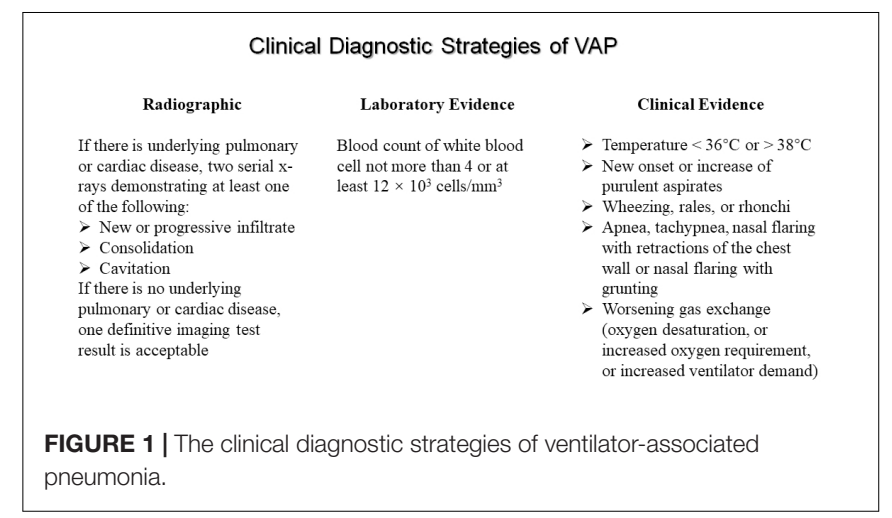

diagnostic criteria for VAP is as follows: (i) radiographic (such as new or progressive and persistent infiltrates, consolidation or cavitation); (ii) laboratory evidence (such as blood count of white blood cell not more than 4 or at least $12 \times 10^{3}$ cells $/ \mathrm{mm}^{3}$ ); (iii) clinical evidence (such as temperature $<36^{\circ} \mathrm{C}$ or $>38^{\circ} \mathrm{C}$, new onset or increase of purulent aspirates, wheezing, rales, rhonchi, or worsening gas exchange) (Grgurich et al., 2013; Timsit et al., 2017a; Torres et al., 2017; Metersky and Kalil, 2018; Vazquez Guillamet and Kollef, 2018).

In addition, microbiologic criteria are also an important element for VAP in a clinical context, such as positive culture results from suctioned sputum, bronchoscopy, blind bronchoalveolar lavage (BAL), or pleural fluid. Although not required to diagnose VAP, serial cultures and microscopic assessments of tracheal aspirate samples during treatment can be useful gauges of the patient's response to antibiotics (Mariki et al., 2014; Fernandez-Barat et al., 2017). VAP can also be divided into early- and late-onset VAP. VAP developing within 4 days of admission are defined as early-onset VAP, which are usually caused by microorganisms sensitive to antibiotics. VAP occurring more than 4 days after admission are defined as late-onset VAP, which are most commonly associated with MDR pathogens and related to higher mortality than early-onset VAP (Nguile-Makao et al., 2010; Martin-Loeches et al., 2015; Torres et al., 2017).

\section{CAUSATIVE PATHOGENS AND RISK FACTORS OF VAP}

A lot of microbes were detected as a causative agent of VAP, the common pathogens of VAP include Gram-negative bacteria such as P. aeruginosa, Escherichia coli, Acinetobacter species, and K. pneumoniae, and Gram-positive bacteria such as Staphylococcus aureus (Chi et al., 2012; Ding et al., 2016). For fungal VAP, because the Candida species are commonly cultured in respiratory samples, it is rarely an etiology of VAP, rarely causes invasive disease, and it is not recommended to use the routine administration of antifungal therapy when Candida species are found in the pulmonary secretions of mechanical ventilation patients (Kalil et al., 2016). Two groups of risk factors for VAP have been identified, including host-related factors and ventilation-related factors. For example, medical history, gender, age, neurological disorders and comorbidities such as 
acute respiratory distress syndrome (ARDS), chronic obstructive pulmonary disease (COPD), ulcer disease, organ failure, and immunosuppression are particularly important causes of VAP. In addition, ventilation-related factors usually include duration of the mechanical ventilation, reintubation, absence of subglottic secretion drainage, nasogastric tubes, tracheostomy, intracuff pressure of less than $20 \mathrm{~cm} \mathrm{H}_{2} \mathrm{O}$, and prior intravenous antibiotic use within 90 days. The causative pathogens and risk factors for VAP are listed in Table 1 (Lau et al., 2015; Kalil et al., 2016; Gupta et al., 2017; Schreiber and Shorr, 2017; Timsit et al., 2017a,b; Kidd et al., 2018; Vandana Kalwaje and Rello, 2018).

\section{STRATEGIES FOR PREVENTION OF VAP}

Multiple international guidelines regarding the prevention of VAP are available, and the current preventive strategies for VAP are mainly directed at colonization and aspiration modification (Table 2).

\section{Minimize Ventilator Exposure}

The first choice for lowering VAP risk is minimizing a patient's exposure to mechanical ventilation (Klompas, 2015; Boltey et al., 2017). The use of non-invasive ventilation approaches is encouraged, such as bi-level positive airway pressure (BiPAP) or continuous positive airway pressure (CPAP). If mechanical ventilation can't be avoided, work to minimize its duration. Ventilator weaning protocols (for example, daily interruption of sedation and coordination with a spontaneous breathing trial) or evidence-based care bundles can be effective in shortening mechanical ventilation duration.

\section{Intensive Oral Care}

The oral health quickly deteriorates in mechanically ventilated patients, and professional oral hygiene care is believed to help reduce the risk of VAP (Soh et al., 2011). The bacterial load presented in the teeth, gums, tongue, and oral mucosa is different
TABLE 2 | Strategies for prevention of VAP.

VAP preventive measures

minimize ventilator exposure

intensive oral care

aspiration of subglottic secretions

maintain optimal positioning and encourage mobility

prophylactic probiotics

VAP, ventilator-associated pneumonia.

between patients with or without treated with antibiotic therapy and mechanical ventilation (Torres et al., 1993; Shi et al., 2013). Chlorhexidine, a broad-spectrum antiseptic agent, has been shown to reduce the incidence of VAP when used for oral care. Zand et al. (2017) have suggested that oral decontamination with $2 \%$ is more effective in the prevention of VAP and reduction of oropharyngeal colonization compared with $0.2 \%$ chlorhexidine. A previous meta-analysis shows that oral care with chlorhexidine might be effective in reducing VAP incidence in the adult population when administered at $2 \%$ concentration or 4 times/day (Villar et al., 2016). However, Rabello et al. (2018) suggests that administration of chlorhexidine for the prevention of VAP was inconclusive, so further studies are needed to confirm the role of intraoral chlorhexidine in the management of VAP.

\section{Aspiration of Subglottic Secretions}

The core mechanism in the development of VAP is oropharyngeal secretions accumulate above and below the endotracheal cuff, facilitating the drainage into the lower airways, so the subglottic secretion suctioning seems to be a pivotal way to prevent VAP. A recent meta-analysis of 20 randomized controlled trials (RCTs) performed by Mao et al. (2016) suggested that subglottic suctioning reduced the risk for VAP by $45 \%$ compared to the control group, and subglottic secretion suction was recommended for preventing VAP and for reducing ventilation

TABLE 1 | The causative pathogens and risk factors for VAP.

\begin{tabular}{|c|c|c|c|}
\hline \multicolumn{2}{|c|}{ Type of pathogens } & \multicolumn{2}{|c|}{ Risk factors } \\
\hline & & Host-related & Intervention-related \\
\hline Bacterium & $\begin{array}{l}\text { Methicillin-sensitive Staphylococcus aureus } \\
\text { MRSA Pseudomonas aeruginosa Acinetobacter } \\
\text { baumannii Streptococcus pneumoniae } \\
\text { Escherichia coli Klebsiella pneumoniae } \\
\text { Anaerobic bacteria Legionella ESBL-PE }\end{array}$ & $\begin{array}{l}\text { Medical history and underlying illness Male } \\
\text { Age > } 60 \text { years Prior central nervous system } \\
\text { disorder Immunocompromised Acute } \\
\text { underlying diseases Emergent surgery Surgical } \\
\text { history Organ failure ARDS COPD Burns ECOM } \\
\text { Ulcer disease }\end{array}$ & $\begin{array}{l}\text { Peri-operative transfusion of blood products } \\
\text { Duration of the mechanical ventilation } \\
\text { Reintubation Supine head position in patients } \\
\text { receiving enteral nutrition Enteral nutrition } \\
\text { Absence of subglottic secretion drainage } \\
\text { Intra-hospital transports Continuous sedation, } \\
\text { use of paralytic agents Nasogastric tubes } \\
\text { Tracheostomy Frequent ventilator circuit } \\
\text { changes Intracuff pressure of less than } 20 \mathrm{~cm} \\
\mathrm{H}_{2} \mathrm{O} \text { Prior intravenous antibiotic use within } \\
90 \text { days }\end{array}$ \\
\hline
\end{tabular}

\section{Fungus $\quad$ Aspergillus Candida}

Virus Influenza Respiratory syncytial virus

VAP, ventilator-associated pneumonia; MRSA, methicillin-resistant Staphylococcal aureus; ESBL-PE, extended-spectrum $\beta$-lactamase-producing Enterobacteriaceae; $A R D S$, acute respiratory distress syndrome; COPD, chronic obstructive pulmonary disease; ECMO, extra-corporeal membrane oxygenation. 
length, especially in the population at high risk of earlyonset VAP.

\section{Maintain Optimal Positioning and Encourage Mobility}

It has been shown that supine intubated patients have a higher risk of aspiration of gastric contents compared to intubated patients in semi-recumbent position (Keeping the head of the bed elevated between 30 and 45 degrees) (Torres et al., 1992; Orozco-Levi et al., 1995; Elorza Mateos et al., 2011), suggesting that the semi-recumbent patient position might be an effective and easy method to prevent VAP. In addition, although it seems challenging, early mobility might also be important for intubated patients because it results in more ventilator-free days (Boltey et al., 2017; Wutzler et al., 2017).

\section{Probiotics}

Recently, a new strategy in the fight against VAP is the use of probiotics. It is widely believed that probiotic bacteria can decrease the development of VAP through local and systemic actions that improve intestinal barrier function, increase host cell antimicrobial peptides, regulate the composition of the intestinal flora, and reduce overgrowth of pathogenic bacteria and bacterial translocation (Mattar et al., 2002; Mack et al., 2003; Isakow et al., 2007; Kelsall, 2008). Several studies have also suggested that probiotics can be safe and efficacious in the prevention or amelioration of VAP in ICU patients (Gluck and Gebbers, 2003; Morrow et al., 2010; Petrof et al., 2012). We should keep in mind that the side-effects of the probiotics are also existed, such as transfer of antibiotic resistance, toxic effects on the gastrointestinal tract, occurrence of disease sepsis and endocarditis (Ohashi and Ushida, 2009; Wong et al., 2015). The incompatible results between studies may be due to differences in patients and clinical situations, the method of probiotic administration, the criteria used in the diagnosis of VAP and the sample size, or the heterogeneity of the probiotic strains used. Therefore, the current opinion for probiotics is believed that although probiotics are usually considered to be safe and well tolerated, while the wide, well-planned, randomized and multicenter studies are required to verify the efficacy of probiotics against VAP before they can be recommended for routine clinical application.

\section{DRUG STRATEGIES FOR TREATMENT OF VAP}

It is important to note that once VAP is considered likely for a patient, the selection of initial empiric antimicrobials may have great variability among clinical scenarios. However, currently, evidence supporting a standardized approach to the exact initial selection of antimicrobials is lacking. Antibiotic resistance has exponentially increased over the last decade, and the isolation of MDR pathogen has been identified as an independent predictor of initial inadequate antibiotic therapy and increased mortality (Vardakas et al., 2013), and the risk of MDR is based on the local ecological data, previous colonization, and previous antibiotic therapy received by the patients. Moreover, there are lots of attempts to control VAP, such as novel antibacterial agents, inhaled antibiotics and monoclonal antibodies. We summarized the reference approaches adapted from recent recommendations or studies for the management of VAP (Palmer, 2015; Kalil et al., 2016; Gupta et al., 2017; Schreiber and Shorr, 2017; Timsit et al., 2017a; Bassetti et al., 2018; Kidd et al., 2018; Vandana Kalwaje and Rello, 2018), details were shown in Table 3.

\section{Antibiotic}

The aim is to choose antibiotics that target specific pathogens of VAP as narrowly as possible, this will ensure optimal treatment while minimizing overtreatment and negative outcomes. The current recommendations for initial empiric antibiotic selection urge the clinician to consider local microbiology patterns because the inappropriate initial antibiotic choice is associated with increased mortality (Moine et al., 2002; Zahar et al., 2011; Timsit et al., 2017a). In addition to local antibiograms, patient-specific risk factors should be used to identify patients at risk for MDR organisms who may necessitate coverage of methicillin-resistant Staphylococcal aureus (MRSA), extended-spectrum $\beta$-lactamaseproducing Enterobacteriaceae (ESBL-PE), Pseudomonas species, Klebsiella species, or A. baumannii until susceptibilities are available (Lee et al., 2013; Duszynska et al., 2015; Timsit et al., 2017b). Antibiotic regimens for VAP are to be treated for a short course (7 or 8 days) according to the recommendation, because the available data suggest there is no significant difference between short-course ( 7 or 8 days) and long-course (10-15 days) antibiotic regimens in regard to mortality, treatment failure, recurrent pneumonia, or duration of mechanical ventilation (Dimopoulos et al., 2013). The longer courses may be appropriate in some circumstances where the patient may have a delayed clinical response. When it comes to combination therapy, a meta-analysis was performed by Aarts et al. (2008) to evaluate the role of combination therapy as empiric treatment for VAP, which was included in 41 trials and 7,015 patients, the results suggest that rates of mortality and treatment failure between monotherapy and combination therapy are similar, while the adverse events are found to be slightly higher in the combination group. Meanwhile, it is critical that to regularly monitor the pattern of MDR organisms in ICU in the management of VAP, and effective national- and state-level monitoring of resistance patterns, antibiotic policy, and draft guidelines are needed to maintain the effectiveness of antimicrobials and for better VAP control (Gupta et al., 2017). In the past decades, lots of new antibiotics against MDR have been approved for the therapeutic intervention of VAP, and other agents are being investigated, such as tedizolid, meropenem-vaborbactam, imipenem-relebactam, ceftolozane-tazobactam, ceftazidime-avibactam, and plazomicin (Jia and Jia, 2016; Bassetti et al., 2018). We believe that these new approved and investigational agents for the treatment of VAP represent promising options to preserve and enhance our antibiotic choices in the future.

\section{Inhaled Antibiotics}

It was observed in some studies that inhalation antibiotics may have beneficial effect in the clinical cure of VAP 
TABLE 3 | Drug strategies for treatment of VAP.

\begin{tabular}{|c|c|c|}
\hline Category & Strategies & Notes \\
\hline \multicolumn{3}{|l|}{$\begin{array}{l}\text { Intravenous } \\
\text { antibiotics }\end{array}$} \\
\hline \multirow{3}{*}{$\begin{array}{l}\text { Without risk } \\
\text { factors }\end{array}$} & Piperacillin-tazobactam 4.5 g IV q6h & - \\
\hline & Cefepime 2 g IV q8h & - \\
\hline & Levofloxacin 750 mg IV daily & - \\
\hline \multirow[t]{3}{*}{ Gram-positive } & $\begin{array}{l}\text { Vancomycin } 15 \mathrm{mg} / \mathrm{kg} \text { IV q8-12h } \\
\text { (consider a loading dose of } \\
25-30 \mathrm{mg} / \mathrm{kg} \times 1 \text { for severe illness) }\end{array}$ & - \\
\hline & Linezolid 600 mg IV q12h & - \\
\hline & Tedizolid 200 mg oral or IV q24h & $\begin{array}{l}\text { Phase III for HAP and } \\
\text { VAP (NCT02019420) }\end{array}$ \\
\hline \multirow[t]{17}{*}{ Gram-negative } & Piperacillin-tazobactam 4.5 g IV q6h & - \\
\hline & Cefepime or ceftazidime 2 g IV q8h & - \\
\hline & Ceftolozane-tazobactam 3 g IV q8h & $\begin{array}{l}\text { Phase III trial for VAP, } \\
\text { HAP (NCT02070757) }\end{array}$ \\
\hline & Ceftazidime-avibactam $2.5 \mathrm{~g}$ IV q8h & $\begin{array}{l}\text { Phase III trial for } \\
\text { nosocomial } \\
\text { pneumonia including } \\
\text { VAP (NCT01808092) }\end{array}$ \\
\hline & Levofloxacin 750 mg IV daily & - \\
\hline & Ciprofloxacin 400 mg IV q8h & - \\
\hline & Imipenem 1g IV q8h & - \\
\hline & Meropenem 1 g IV q6h & - \\
\hline & Meropenem-vaborbactam 2 g IV q8h & $\begin{array}{l}\text { Phase III trial for the } \\
\text { treatment of } \\
\text { HAPNAP } \\
\text { (NCT03006679) }\end{array}$ \\
\hline & $\begin{array}{l}\text { Imipenem-relebactam } \\
500 \text { mg/250-125 mg IV q6h }\end{array}$ & $\begin{array}{l}\text { Phase III for VAP, HAP } \\
\text { (NCT02452047); } \\
\text { Phase III for VAP, } \\
\text { HAP (NCT02493764) }\end{array}$ \\
\hline & Aztreonam 2 g IV q8h & - \\
\hline & Amikacin 15-20 mg/kg IV q24h & - \\
\hline & Gentamicin 5-7 mg/kg IV q24h & - \\
\hline & Tobramycin 5-7 mg/kg IV q24h & - \\
\hline & Plazomicin 15 mg/kg IV q24h & $\begin{array}{l}\text { Phase III for BSI, HAP, } \\
\text { VAP (NCT01970371) }\end{array}$ \\
\hline & $\begin{array}{l}\text { Colistin } 5 \mathrm{mg} / \mathrm{kg} \mathrm{IV} \times 1 \text { (loading dose) } \\
\text { followed by } 2.5 \mathrm{mg} \times(1.5 \times \mathrm{CrCl}+30) \\
\mathrm{IV} \text { q12h (maintenance dose) }\end{array}$ & - \\
\hline & $\begin{array}{l}\text { Polymyxin B } 2.5-3.0 \mathrm{mg} / \mathrm{kg} / \mathrm{d} \text { divided in } \\
2 \text { daily IV doses }\end{array}$ & - \\
\hline \multirow{2}{*}{$\begin{array}{l}\text { Inhaled } \\
\text { antibiotics }\end{array}$} & Colistin & Indetermination \\
\hline & $\begin{array}{l}\text { Aminoglycosides (such as sisomycin, } \\
\text { gentamicin, amikacin, and tobramycin) }\end{array}$ & Indetermination \\
\hline
\end{tabular}

IV, intravenous; q, every; VAP, ventilator-associated pneumonia; HAP, hospitalacquired pneumonia.

(Klastersky et al., 1979; Hallal et al., 2007; Lu et al., 2012; Tumbarello et al., 2013; Palmer and Smaldone, 2014). However, other studies showed no statistically significant effect in their primary outcome (Le Conte et al., 2000; Rattanaumpawan et al., 2010; Lu et al., 2011; Niederman et al., 2012; Doshi et al., 2013). A previously published meta-analysis of 6 randomized controlled trials and 6 observational studies performed in VAP shows that the use of inhalation antibiotics is associated with higher rates of clinical cure, while the statistical significance is not reached in the meta-regression analysis (Zampieri et al., 2015). There is a nonsignificant improvement in clinical cure when using inhalation antibiotics as an adjunctive treatment in VAP besides using systemic antibiotics until now, and more evidence from larger randomized controlled trials (RCTs) is needed to confirm the appropriateness of this adjunctive treatment (Russell et al., 2016).

\section{Monoclonal Antibodies}

At present, the drugs in development for the treatment of VAP can significantly improve the therapeutic options available. The possibility to administer directed therapy with monoclonal antibodies to specific pathogens is an exciting strategy in the fight against widespread resistance of MDR organisms. For example, Que et al. (2014) have reported that the full course of panobacumab, an anti-lipopolysaccharide (LPS) immunoglobulin M monoclonal antibody, adjunctive immunotherapy targeting serotype-specific LPS of $P$. aeruginosa O11 may have improved the clinical outcome of patients presenting with nosocomial pneumonia. Different monoclonal antibodies, including panobacumab (Lazar et al., 2009; Horn et al., 2010), KB001 (Shime et al., 2001; Baer et al., 2009; Francois et al., 2012), and MEDI4893 (Hua et al., 2014, 2015), directed against components of $P$. aeruginosa or $S$. aureus are now being studied for nosocomial respiratory infections. However, most of these studies are in very preliminary stages of development, and it is actually impossible to know what their future role in the therapy of VAP will be. The use of certain monoclonal antibodies directed against some specific serotypes of specific pathogens is an interesting approach to try to reduce antimicrobial resistance.

\section{FUTURE DIRECTIONS}

In the coming decade, VAP will continue to be a major infection in the ICU. We anticipate the need for better epidemiologic and diagnostic tools that will inform us about the true incidence of these infections and the impact of specific prevention and treatment strategies. For prevention, a VAP care bundle, nursing care and education are recommended; these strategies have been shown to decrease the health care costs and antimicrobials use, length of ICU stay, and the need of mechanical ventilation therapy (Aiken et al., 2014; Okgun Alcan et al., 2016; Nogueira et al., 2017; Jansson et al., 2019). In addition, a recent study has suggested that $N$-acetyl-cysteine (NAC) is safe and effective to prevent and delay the development of VAP (Sharafkhah and Abdolrazaghnejad, 2018). It's also very important to use new diagnostic methods (such as nextgeneration sequencing technology, phase contrast X-ray imaging, lung ultrasonography (Bouhemad et al., 2018), and the electronic nose) and/or new biomarkers (such as phosphatidylinositol 3kinase regulatory subunit and sarcoplasmic reticulum calcium transporting ATPase) (Jamaati et al., 2018), to find the bacteriology and its frequency of MDR pathogens and to guide more accurate and focused initial antibiotic therapy. Moreover, 
it is very urgent to develop new drugs for MDR pathogens because of increasing antimicrobial resistance. There will also be further exploration of optimized antibiotic pharmacokinetics (PK) and pharmacodynamics (PD), which will allow us to improve the effectiveness of the treatments of pneumonia caused by MDR organisms as well as to achieve a lower rate of adverse effects. We believe that with focus on VAP epidemiology, diagnostic methods, bacteriology, prevention, and therapy, we will see further improvement in the outcomes of our patients.

\section{CONCLUSION}

Ventilator-associated pneumonia is an important cause of morbidity and mortality in mechanically ventilated patients, and many strategies have been proposed for the prevention and treatment of this disease. Successful prevention of VAP can save on total costs and is possible using a multidisciplinary clinical and administrative approach. In addition, the early appropriate antimicrobial therapy is critical to improving clinical outcomes for patients with VAP. Unfortunately, clinician failure is common, with about $70 \%$ of patients receiving inadequate initial empiric therapy for VAP. Some new antibiotics such as tedizolid,

\section{REFERENCES}

Aarts, M. A., Hancock, J. N., Heyland, D., McLeod, R. S. and Marshall, J. C. (2008). Empiric antibiotic therapy for suspected ventilator-associated pneumonia: a systematic review and meta-analysis of randomized trials. Crit. Care. Med. 36, 108-117. doi: 10.1097/01.ccm.0000297956.27474.9d

Aiken, L. H., Sloane, D. M., Bruyneel, L., Van den Heede, K., Griffiths, P., Busse, R., et al. (2014). Nurse staffing and education and hospital mortality in nine European countries: a retrospective observational study. Lancet 383, 1824-1830. doi: 10.1016/s0140-6736(13)62631-8

Awad, L. S., Abdallah, D. I., Mugharbil, A. M., Jisr, T. H., Droubi, N. S., ElRajab, N. A., et al. (2018). An antibiotic stewardship exercise in the ICU: building a treatment algorithm for the management of ventilator-associated pneumonia based on local epidemiology and the 2016 Infectious Diseases Society of America/American Thoracic Society guidelines. Infect. Drug Resist. 11, 17-28. doi: 10.2147/idr.s145827

Baer, M., Sawa, T., Flynn, P., Luehrsen, K., Martinez, D., Wiener-Kronish, J. P., et al. (2009). An engineered human antibody fab fragment specific for Pseudomonas aeruginosa PcrV antigen has potent antibacterial activity. Infect. Immun. 77, 1083-1090. doi: 10.1128/iai.00815-08

Balas, M. C., Vasilevskis, E. E., Olsen, K. M., Schmid, K. K., Shostrom, V., Cohen, M. Z., et al. (2014). Effectiveness and safety of the awakening and breathing coordination, delirium monitoring/management, and early exercise/mobility bundle. Crit. Care Med. 42, 1024-1036. doi: $10.1097 / \mathrm{ccm} .0000000000000129$

Bassetti, M., Vena, A., Castaldo, N., Righi, E., and Peghin, M. (2018). New antibiotics for ventilator-associated pneumonia. Curr. Opin. Infect. Dis. 31, 177-186. doi: 10.1097/qco.0000000000000438

Boltey, E., Yakusheva, O., and Costa, D. K. (2017). 5 Nursing strategies to prevent ventilator-associated pneumonia. Am. Nurse Today 12, 42-43.

Bouhemad, B., Dransart-Raye, O., Mojoli, F., and Mongodi, S. (2018). Lung ultrasound for diagnosis and monitoring of ventilator-associated pneumonia. Ann. Transl. Med. 6:418. doi: 10.21037/atm.2018.10.46

Carron, M., Freo, U., BaHammam, A. S., Dellweg, D., Guarracino, F., Cosentini, R., et al. (2013). Complications of non-invasive ventilation techniques: a comprehensive qualitative review of randomized trials. Br. J. Anaesth. 110, 896-914. doi: 10.1093/bja/aet070

Charles, M. P., Kali, A., Easow, J. M., Joseph, N. M., Ravishankar, M., Srinivasan, S., et al. (2014). Ventilator-associated pneumonia. Australas. Med. J. 7, 334-344. doi: $10.4066 / \mathrm{amj} .2014 .2105$ meropenem-vaborbactam, imipenem-relebactam, ceftazidimeavibactam, ceftolozane-tazobactam, and plazomicin, are being developed for VAP to combat our increasingly resistant infecting organisms. Meanwhile, some new options and choices for the management of VAP are also being developed, including inhaled antibiotics and monoclonal antibodies. Future studies are necessary to evaluate these therapeutic strategies in the management of VAP. We hope that the present overview contributes to the prevention and control of VAP.

\section{AUTHOR CONTRIBUTIONS}

ML and XX conceived the general idea. XX and ML wrote the first draft. TH, JL, and ML revised the manuscript. All authors read and approved the final manuscript.

\section{FUNDING}

This study was supported by the National Natural Science Foundation of China (Grant Nos. 81330002 and 81800052).

Chi, S. Y., Kim, T. O., Park, C. W., Yu, J. Y., Lee, B., Lee, H. S., et al. (2012). Bacterial pathogens of ventilator associated pneumonia in a tertiary referral hospital. Tuberc. Respir. Dis. 73, 32-37. doi: 10.4046/trd.2012.73.1.32

Chung, D. R., Song, J. H., Kim, S. H., Thamlikitkul, V., Huang, S. G., Wang, H., et al. (2011). High prevalence of multidrug-resistant nonfermenters in hospitalacquired pneumonia in Asia. Am. J. Respir. Crit. Care Med. 184, 1409-1417. doi: 10.1164/rccm.201102-0349OC

Dasgupta, S., Das, S., Chawan, N. S., and Hazra, A. (2015). Nosocomial infections in the intensive care unit: incidence, risk factors, outcome and associated pathogens in a public tertiary teaching hospital of Eastern India. Indian J. Crit. Care Med. 19, 14-20. doi: 10.4103/0972-5229.148633

Dimopoulos, G., Poulakou, G., Pneumatikos, I. A., Armaganidis, A., Kollef, M. H., and Matthaiou, D. K. (2013). Short- vs long-duration antibiotic regimens for ventilator-associated pneumonia: a systematic review and meta-analysis. Chest 144, 1759-1767. doi: 10.1378/chest.13-0076

Ding, C., Yang, Z., Wang, J., Liu, X., Cao, Y., Pan, Y., et al. (2016). Prevalence of Pseudomonas aeruginosa and antimicrobial-resistant Pseudomonas aeruginosa in patients with pneumonia in mainland China: a systematic review and meta-analysis. Int. J. Infect. Dis. 49, 119-128. doi: 10.1016/j.ijid.2016. 06.014

Doshi, N. M., Cook, C. H., Mount, K. L., Stawicki, S. P., Frazee, E. N., Personett, H. A., et al. (2013). Adjunctive aerosolized colistin for multi-drug resistant gram-negative pneumonia in the critically ill: a retrospective study. $B M C$ Anesthesiol. 13:45. doi: 10.1186/1471-2253-13-45

Duszynska, W., Rosenthal, V. D., Dragan, B., Wegrzyn, P., Mazur, A., Wojtyra, P., et al. (2015). Ventilator-associated pneumonia monitoring according to the INICC project at one centre. Anaesthesiol. Intensive Ther. 47, 34-39. doi: 10. 5603/ait.2015.0004

Elorza Mateos, J., Ania Gonzalez, N., Agreda Sadaba, M., Del Barrio Linares, M., Margall Coscojuela, M. A., and Asiain Erro, M. C. (2011). [Nursing care in the prevention of ventilator-associated pneumonia]. Enferm. Intensiva. 22, 22-30. doi: 10.1016/j.enfi.2010.11.006

Erb, C. T., Patel, B., Orr, J. E., and Bice, T. (2016). Management of Adults with Hospital-acquired and Ventilator-associated Pneumonia. Ann. Am. Thorac. Soc. 13, 2258-2260. doi: 10.1513/AnnalsATS.201608-641CME

Fernandez-Barat, L., Motos, A., and Ranzani, O. T. (2017). Diagnostic value of endotracheal aspirates sonication on ventilator-associated pneumonia microbiologic diagnosis. Microorganisms 5:E62. doi: 10.3390/microorganisms 5030062 
Francois, B., Luyt, C. E., Dugard, A., Wolff, M., Diehl, J. L., Jaber, S., et al. (2012). Safety and pharmacokinetics of an anti-PcrV PEGylated monoclonal antibody fragment in mechanically ventilated patients colonized with Pseudomonas aeruginosa: a randomized,double-blind, placebo-controlled trial. Crit. Care Med. 40, 2320-2326. doi: 10.1097/CCM.0b013e31825334f6

Gluck, U., and Gebbers, J. O. (2003). Ingested probiotics reduce nasal colonization with pathogenic bacteria (Staphylococcus aureus, Streptococcus pneumoniae, and beta-hemolytic streptococci). Am. J. Clin. Nutr. 77, 517-520. doi: 10.1093/ ajcn/77.2.517

Grgurich, P. E., Hudcova, J., Lei, Y., Sarwar, A., and Craven, D. E. (2013). Diagnosis of ventilator-associated pneumonia: controversies and working toward a gold standard. Curr. Opin. Infect. Dis. 26, 140-150. doi: 10.1097/QCO. 0b013e32835ebbd0

Gupta, R., Malik, A., Rizvi, M., Ahmed, M., and Singh, A. (2017). Epidemiology of multidrug-resistant Gram-negative pathogens isolated from ventilatorassociated pneumonia in ICU patients. J. Glob. Antimicrob. Resist. 9, 47-50. doi: 10.1016/j.jgar.2016.12.016

Hallal, A., Cohn, S. M., Namias, N., Habib, F., Baracco, G., Manning, R. J., et al. (2007). Aerosolized tobramycin in the treatment of ventilatorassociated pneumonia: a pilot study. Surg. Infect. 8, 73-82. doi: 10.1089/sur. 2006.051

Horn, M. P., Zuercher, A. W., Imboden, M. A., Rudolf, M. P., Lazar, H., Wu, H., et al. (2010). Preclinical in vitro and in vivo characterization of the fully human monoclonal IgM antibody KBPA101 specific for Pseudomonas aeruginosa serotype IATS-O11. Antimicrob. Agents Chemother. 54, 2338-2344. doi: 10. 1128/aac.01142-09

Hua, L., Cohen, T. S., Shi, Y., Datta, V., Hilliard, J. J., Tkaczyk, C., et al. (2015). MEDI4893* promotes survival and extends the antibiotic treatment window in a Staphylococcus aureus immunocompromised pneumonia model. Antimicrob. Agents Chemother. 59, 4526-4532. doi: 10.1128/aac.00510-15

Hua, L., Hilliard, J. J., Shi, Y., Tkaczyk, C., Cheng, L. I., Yu, X., et al. (2014). Assessment of an anti-alpha-toxin monoclonal antibody for prevention and treatment of Staphylococcus aureus-induced pneumonia. Antimicrob. Agents Chemother. 58, 1108-1117. doi: 10.1128/aac.02190-13

Isakow, W., Morrow, L. E., and Kollef, M. H. (2007). Probiotics for preventing and treating nosocomial infections: review of current evidence and recommendations. Chest 132, 286-294. doi: 10.1378/chest.06-2156

Jamaati, H., Bahrami, N., Daustany, M., Tabarsi, P., Farzanegan, B., and Hashemian, S. M., et al. (2018). Investigating PIK3R3 and ATp2A1 Genes Expressions in Ventilator-Associated Pneumonia Patients Admitted to the Intensive Care Unit of Masih Daneshvari Hospital in 2016. Rep. Biochem. Mol. Biol. 6, 118-124.

Jansson, M. M., Syrjala, H. P., and Ala-Kokko, T. I. (2019). Association of nurse staffing and nursing workload with ventilator-associated pneumonia and mortality: a prospective, single-center cohort study. J. Hosp. Infect. 101, 257-263. doi: 10.1016/j.jhin.2018.12.001

Jia, R., and Jia, L. (2016). Advances in antibiotic therapy in the critically ill. Crit. Care 20:393. doi: 10.1186/s13054-016-1544-6

Kalil, A. C., Metersky, M. L., Klompas, M., Muscedere, J., Sweeney, D. A., Palmer, L. B., et al. (2016). Management of Adults With Hospital-acquired and Ventilator-associated Pneumonia: 2016 Clinical Practice Guidelines by the Infectious Diseases Society of America and the American Thoracic Society. Clin. Infect. Dis. 63, e61-e111. doi: 10.1093/cid/ciw353

Kelsall, B. L. (2008). Innate and adaptive mechanisms to control [corrected] pathological intestinal inflammation. J. Pathol. 214, 242-259. doi: 10.1002/path. 2286

Kidd, J. M., Kuti, J. L., and Nicolau, D. P. (2018). Novel pharmacotherapy for the treatment of hospital-acquired and ventilator-associated pneumonia caused by resistant gram-negative bacteria. Expert. Opin. Pharmacother. 19, 397-408. doi: 10.1080/14656566.2018.1438408

Klastersky, J., Carpentier-Meunier, F., Kahan-Coppens, L., and Thys, J. P. (1979). Endotracheally administered antibiotics for gram-negative bronchopneumonia. Chest 75, 586-591. doi: 10.1378/chest.75.5.586

Klompas, M. (2015). Potential strategies to prevent ventilator-associated events. Am. J. Respir. Crit. Care Med. 192, 1420-1430. doi: 10.1164/rccm.201506$1161 \mathrm{CI}$

Klompas, M., Anderson, D., Trick, W., Babcock, H., Kerlin, M. P., Li, L., et al. (2015). The preventability of ventilator-associated events. The CDC Prevention
Epicenters Wake Up and Breathe Collaborative. Am. J. Respir. Crit. Care Med. 191, 292-301. doi: 10.1164/rccm.201407-1394OC

Klompas, M., Branson, R., Eichenwald, E. C., Greene, L. R., Howell, M. D., Lee, G., et al. (2014). Strategies to prevent ventilator-associated pneumonia in acute care hospitals: 2014 update. Infect. Control Hosp. Epidemiol. 35(Suppl. 2), S133-S154. doi: 10.1086/677144

Lau, A. C., So, H. M., Tang, S. L., Yeung, A., Lam, S. M., and Yan, W. W. (2015). Prevention of ventilator-associated pneumonia. Hong Kong Med. J. 21, 61-68. doi: 10.12809/hkmj144367

Lazar, H., Horn, M. P., Zuercher, A. W., Imboden, M. A., Durrer, P., Seiberling, M., et al. (2009). Pharmacokinetics and safety profile of the human anti-Pseudomonas aeruginosa serotype $\mathrm{O} 11$ immunoglobulin $\mathrm{M}$ monoclonal antibody KBPA-101 in healthy volunteers. Antimicrob. Agents Chemother. 53, 3442-3446. doi: 10.1128/aac.01699-08

Le Conte, P., Potel, G., Clementi, E., Legras, A., Villers, D., Bironneau, E., et al. (2000). [Administration of tobramycin aerosols in patients with nosocomial pneumonia: a preliminary study]. Presse Med. 29, 76-78.

Lee, M. S., Walker, V., Chen, L. F., Sexton, D. J., and Anderson, D. J. (2013). The epidemiology of ventilator-associated pneumonia in a network of community hospitals: a prospective multicenter study. Infect. Control Hosp. Epidemiol. 34, 657-662. doi: 10.1086/670991

Li Bassi, G., Senussi, T., and Aguilera Xiol, E. (2017). Prevention of ventilatorassociated pneumonia. Curr. Opin. Infect Dis. 30, 214-220. doi: 10.1097/qco. 0000000000000358

Lu, Q., Luo, R., Bodin, L., Yang, J., Zahr, N., Aubry, A., et al. (2012). Efficacy of high-dose nebulized colistin in ventilator-associated pneumonia caused by multidrug-resistant Pseudomonas aeruginosa and Acinetobacter baumannii. Anesthesiology 117, 1335-1347. doi: 10.1097/ALN.0b013e31827515de

Lu, Q., Yang, J., Liu, Z., Gutierrez, C., Aymard, G., and Rouby, J. J. (2011). Nebulized ceftazidime and amikacin in ventilator-associated pneumonia caused by Pseudomonas aeruginosa. Am. J. Respir. Crit. Care Med. 184, 106-115. doi: 10.1164/rccm.201011-1894OC

Mack, D. R., Ahrne, S., Hyde, L., Wei, S., and Hollingsworth, M. A. (2003). Extracellular MUC3 mucin secretion follows adherence of Lactobacillus strains to intestinal epithelial cells in vitro. Gut 52, 827-833. doi: 10.1136/gut.52. 6.827

Magill, S. S., Klompas, M., Balk, R., Burns, S. M., Deutschman, C. S., Diekema, D., et al. (2013). Developing a new, national approach to surveillance for ventilator-associated events*. Crit. Care Med. 41, 2467-2475. doi: 10.1097/ CCM.0b013e3182a262db

Mao, Z., Gao, L., Wang, G., Liu, C., Zhao, Y., Gu, W., et al. (2016). Subglottic secretion suction for preventing ventilator-associated pneumonia: an updated meta-analysis and trial sequential analysis. Crit. Care 20:353. doi: 10.1186/ s13054-016-1527-7

Mariki, P., Rellosa, N., Wratney, A., Stockwell, D., Berger, J., Song, X., et al. (2014). Application of a modified microbiologic criterion for identifying pediatric ventilator-associated pneumonia. Am. J. Infect. Control 42, 1079-1083. doi: 10.1016/j.ajic.2014.06.014

Martin-Loeches, I., Torres, A., Rinaudo, M., Terraneo, S., de Rosa, F., Ramirez, P., et al. (2015). Resistance patterns and outcomes in intensive care unit (ICU)acquired pneumonia. Validation of European Centre for Disease Prevention and Control (ECDC) and the Centers for Disease Control and Prevention (CDC) classification of multidrug resistant organisms. J. Infect. 70, 213-222. doi: 10.1016/j.jinf.2014.10.004

Mathai, A. S., Phillips, A., and Isaac, R. (2016). Ventilator-associated pneumonia: a persistent healthcare problem in Indian Intensive Care Units! Lung India. 33, 512-516. doi: 10.4103/0970-2113.188971

Mattar, A. F., Teitelbaum, D. H., Drongowski, R. A., Yongyi, F., Harmon, C. M., and Coran, A. G. (2002). Probiotics up-regulate MUC-2 mucin gene expression in a Caco-2 cell-culture model. Pediatr. Surg. Int. 18, 586-590. doi: 10.1007/ s00383-002-0855-7

Metersky, M. L., and Kalil, A. C. (2018). Management of ventilator-associated pneumonia: guidelines. Clin. Chest Med. 39, 797-808. doi: 10.1016/j.ccm.2018. 08.002

Moine, P., Timsit, J. F., De Lassence, A., Troche, G., Fosse, J. P., Alberti, C., et al. (2002). Mortality associated with late-onset pneumonia in the intensive care unit: results of a multi-center cohort study. Intensive Care Med. 28, 154-163. doi: $10.1007 / \mathrm{s} 00134-001-1172-7$ 
Morrow, L. E., Kollef, M. H., and Casale, T. B. (2010). Probiotic prophylaxis of ventilator-associated pneumonia: a blinded, randomized, controlled trial. Am. J. Respir. Crit. Care Med. 182, 1058-1064. doi: 10.1164/rccm.200912-1853OC

Nair, G. B., and Niederman, M. S. (2015). Ventilator-associated pneumonia: present understanding and ongoing debates. Intensive Care Med. 41, 34-48. doi: 10.1007/s00134-014-3564-5

Nguile-Makao, M., Zahar, J. R., Francais, A., Tabah, A., Garrouste-Orgeas, M., Allaouchiche, B., et al. (2010). Attributable mortality of ventilator-associated pneumonia: respective impact of main characteristics at ICU admission and VAP onset using conditional logistic regression and multi-state models. Intensive Care Med. 36, 781-789. doi: 10.1007/s00134-010-1824-6

Nicolosi, L. N., del Carmen Rubio, M., Martinez, C. D., Gonzalez, N. N., and Cruz, M. E. (2014). Effect of oral hygiene and $0.12 \%$ chlorhexidine gluconate oral rinse in preventing ventilator-associated pneumonia after cardiovascular surgery. Respir. Care 59, 504-509. doi: 10.4187/respcare.02666

Niederman, M. S., Chastre, J., Corkery, K., Fink, J. B., Luyt, C. E., and Garcia, M. S. (2012). BAY41-6551 achieves bactericidal tracheal aspirate amikacin concentrations in mechanically ventilated patients with Gram-negative pneumonia. Intensive Care Med. 38, 263-271. doi: 10.1007/s00134-0112420-0

Nogueira, T. D. A., Menegueti, M. G., Perdona, G., Auxiliadora-Martins, M., Fugulin, F. M. T., and Laus, A. M. (2017). Effect of nursing care hours on the outcomes of Intensive Care assistance. PLoS One 12:e0188241. doi: 10.1371/ journal.pone.0188241

Ohashi, Y., and Ushida, K. (2009). Health-beneficial effects of probiotics: its mode of action. Anim. Sci. J. 80, 361-371. doi: 10.1111/j.1740-0929.2009.00645.x

Okgun Alcan, A., Demir Korkmaz, F., and Uyar, M. (2016). Prevention of ventilator-associated pneumonia: use of the care bundle approach. Am. J. Infect. Control 44, e173-e176. doi: 10.1016/j.ajic.2016.04.237

Orozco-Levi, M., Torres, A., Ferrer, M., Piera, C., el-Ebiary, M., de la Bellacasa, J. P., et al. (1995). Semirecumbent position protects from pulmonary aspiration but not completely from gastroesophageal reflux in mechanically ventilated patients. Am. J. Respir. Crit. Care Med. 152, 1387-1390. doi: 10.1164/ajrccm. 152.4.7551400

Palmer, L. B. (2015). Ventilator-associated infection: the role for inhaled antibiotics. Curr. Opin. Pulm. Med. 21, 239-249. doi: 10.1097/mcp.0000000 000000160

Palmer, L. B., and Smaldone, G. C. (2014). Reduction of bacterial resistance with inhaled antibiotics in the intensive care unit. Am. J. Respir. Crit. Care Med. 189, 1225-1233. doi: 10.1164/rccm.201312-21610C

Petrof, E. O., Dhaliwal, R., Manzanares, W., Johnstone, J., Cook, D.Heyland, D. K. (2012). Probiotics in the critically ill: a systematic review of the randomized trial evidence. Crit. Care Med. 40, 3290-3302. doi: 10.1097/CCM.0b013e318260cc33

Que, Y. A., Lazar, H., Wolff, M., Francois, B., Laterre, P. F., Mercier, E., et al. (2014). Assessment of panobacumab as adjunctive immunotherapy for the treatment of nosocomial Pseudomonas aeruginosa pneumonia. Eur. J. Clin. Microbiol. Infect. Dis. 33, 1861-1867. doi: 10.1007/s10096-014-2156-1

Rabello, F., Araujo, V. E., and Magalhaes, S. (2018). Effectiveness of oral chlorhexidine for the prevention of nosocomial pneumonia and ventilatorassociated pneumonia in intensive care units: overview of systematic reviews. Int. J. Dent. Hyg. 16, 441-449. doi: 10.1111/idh.12336

Rattanaumpawan, P., Lorsutthitham, J., Ungprasert, P., Angkasekwinai, N., and Thamlikitkul, V. (2010). Randomized controlled trial of nebulized colistimethate sodium as adjunctive therapy of ventilator-associated pneumonia caused by Gram-negative bacteria. J. Antimicrob. Chemother. 65, 2645-2649. doi: 10.1093/jac/dkq360

Rhodes, N. J., Cruce, C. E., and O’Donnell, J. N. (2018). Resistance trends and treatment options in gram-negative ventilator-associated pneumonia. Curr. Infect. Dis. Rep. 20:3. doi: 10.1007/s11908-018-0609-x

Russell, C. J., Shiroishi, M. S., Siantz, E., Wu, B. W., and Patino, C. M. (2016). The use of inhaled antibiotic therapy in the treatment of ventilator-associated pneumonia and tracheobronchitis: a systematic review. BMC Pulm. Med. 16:40. doi: 10.1186/s12890-016-0202-8

Schreiber, M. P., and Shorr, A. F. (2017). Challenges and opportunities in the treatment of ventilator-associated pneumonia. Expert. Rev. Anti. Infect. Ther. 15, 23-32. doi: 10.1080/14787210.2017.1250625

Sharafkhah, M., and Abdolrazaghnejad, A. (2018). Safety and efficacy of N-acetylcysteine for prophylaxis of ventilator-associated pneumonia: a randomized, double blind, placebo-controlled clinical trial. Med. Gas. Res. 8, 19-23. doi: 10.4103/2045-9912.229599

Shi, Z., Xie, H., Wang, P., Zhang, Q., Wu, Y., Chen, E., et al. (2013). Oral hygiene care for critically ill patients to prevent ventilator-associated pneumonia. Cochrane Database Syst. Rev. 13:Cd008367. doi: 10.1002/14651858.CD 008367

Shime, N., Sawa, T., Fujimoto, J., Faure, K., Allmond, L. R., Karaca, T., et al. (2001). Therapeutic administration of anti-PcrV F(ab')(2) in sepsis associated with Pseudomonas aeruginosa. J. Immunol. 167, 5880-5886. doi: 10.4049/jimmunol. 167.10 .5880

Soh, K. L., Soh, K. G., Japar, S., Raman, R. A., and Davidson, P. M. (2011). A crosssectional study on nurses' oral care practice for mechanically ventilated patients in Malaysia. J. Clin. Nurs. 20, 733-742. doi: 10.1111/j.1365-2702.2010.03579.x

Tablan, O. C., Anderson, L. J., Besser, R., Bridges, C., and Hajjeh, R. (2004). Guidelines for preventing health-care-associated pneumonia, 2003: recommendations of CDC and the Healthcare Infection Control Practices Advisory Committee. MMWR Recomm. Rep. 53, 1-36.

Tejerina, E., Esteban, A., Fernandez-Segoviano, P., Frutos-Vivar, F., Aramburu, J., Ballesteros, D., et al. (2010). Accuracy of clinical definitions of ventilatorassociated pneumonia: comparison with autopsy findings. J. Crit. Care. 25, 62-68. doi: 10.1016/j.jcrc.2009.05.008

Timsit, J. F., Esaied, W., Neuville, M., Bouadma, L., and Mourvllier, B. (2017a). Update on ventilator-associated pneumonia. F1000Res. 6:2061. doi: 10.12688/ f1000research.12222.1

Timsit, J. F., Pilmis, B., and Zahar, J. R. (2017b). How should we treat hospitalacquired and ventilator-associated pneumonia caused by extended-spectrum beta-lactamase-producing Enterobacteriaceae? Semin. Respir. Crit. Care Med. 38, 287-300. doi: 10.1055/s-0037-1603112

Torres, A., el-Ebiary, M., Gonzalez, J., Ferrer, M., Puig de la Bellacasa, J., Gene, A., et al. (1993). Gastric and pharyngeal flora in nosocomial pneumonia acquired during mechanical ventilation. Am. Rev. Respir. Dis. 148, 352-357. doi: 10.1164/ ajrccm/148.2.352

Torres, A., Niederman, M. S., Chastre, J., Ewig, S., Fernandez-Vandellos, P., Hanberger, H., et al. (2017). International ERS/ESICM/ESCMID/ALAT guidelines for the management of hospital-acquired pneumonia and ventilatorassociated pneumonia: guidelines for the management of hospital-acquired pneumonia (HAP)/ventilator-associated pneumonia (VAP) of the European Respiratory Society (ERS), European Society of Intensive Care Medicine (ESICM), European Society of Clinical Microbiology and Infectious Diseases (ESCMID) and Asociacion Latinoamericana del Torax (ALAT). Eur. Respir. J. 50:1700582. doi: 10.1183/13993003.00582-2017

Torres, A., Serra-Batlles, J., Ros, E., Piera, C., Puig de la Bellacasa, J., Cobos, A., et al. (1992). Pulmonary aspiration of gastric contents in patients receiving mechanical ventilation: the effect of body position. Ann. Intern. Med. 116, 540-543. doi: 10.7326/0003-4819-116-7-540

Torres, A., and Carlet, J. (2001). Ventilator-associated pneumonia. European Task Force on ventilator-associated pneumonia. Eur. Respir. J. 17, 1034-1045. doi: 10.1183/09031936.01.17510340

Tumbarello, M., De Pascale, G., Trecarichi, E. M., De Martino, S., Bello, G., Maviglia, R., et al. (2013). Effect of aerosolized colistin as adjunctive treatment on the outcomes of microbiologically documented ventilator-associated pneumonia caused by colistin-only susceptible gram-negative bacteria. Chest 144, 1768-1775. doi: 10.1378/chest.13-1018

Vandana Kalwaje, E., and Rello, J. (2018). Management of ventilator-associated pneumonia: need for a personalized approach. Expert Rev. Anti. Infect. Ther. 16, 641-653. doi: 10.1080/14787210.2018.1500899

Vardakas, K. Z., Rafailidis, P. I., Konstantelias, A. A., and Falagas, M. E. (2013). Predictors of mortality in patients with infections due to multi-drug resistant Gram negative bacteria: the study, the patient, the bug or the drug? J. Infect. 66, 401-414. doi: 10.1016/j.jinf.2012.10.028

Vazquez Guillamet, C., and Kollef, M. H. (2018). Is zero ventilator-associated pneumonia achievable?: practical approaches to ventilator-associated pneumonia prevention. Clin. Chest Med. 39, 809-822. doi: 10.1016/j.ccm. 2018.08.004

Villar, C. C., Pannuti, C. M., Nery, D. M., Morillo, C. M., Carmona, M. J., and Romito, G. A. (2016). Effectiveness of intraoral chlorhexidine protocols in the prevention of ventilator-associated pneumonia: meta-analysis and systematic review. Respir. Care, 61, 1245-1259. doi: 10.4187/respcare.04610 
Weber, D. J., Rutala, W. A., Sickbert-Bennett, E. E., Samsa, G. P., Brown, V., and Niederman, M. S. (2007). Microbiology of ventilator-associated pneumonia compared with that of hospital-acquired pneumonia. Infect. Control Hosp. Epidemiol. 28, 825-831. doi: 10.1086/518460

Weiner, L. M., Webb, A. K., Limbago, B., Dudeck, M. A., Patel, J., Kallen, A. J., et al. (2016). Antimicrobial-resistant pathogens associated with healthcareassociated infections: summary of data reported to the national healthcare safety network at the centers for disease control and prevention, 2011-2014. Infect. Control Hosp. Epidemiol. 37, 1288-1301. doi: 10.1017/ice.2016.174

Wong, A., Ngu, D. Y., Dan, L. A., Ooi, A., and Lim, R. L. (2015). Detection of antibiotic resistance in probiotics of dietary supplements. Nutr. J. 14:95. doi: 10.1186/s12937-015-0084-2

Wutzler, S., Sturm, K., Lustenberger, T., Wyen, H., Zacharowksi, K., Marzi, I., et al. (2017). Kinetic therapy in multiple trauma patients with severe thoracic trauma: a treatment option to reduce ventilator time and improve outcome. Eur. J. Trauma. Emerg. Surg. 43, 155-161. doi: 10.1007/s00068-016-0692-3

Zahar, J. R., Timsit, J. F., Garrouste-Orgeas, M., Francais, A., Vesin, A., DescorpsDeclere, A., et al. (2011). Outcomes in severe sepsis and patients with septic shock: pathogen species and infection sites are not associated with mortality. Crit. Care Med. 39, 1886-1895. doi: 10.1097/CCM.0b013e31821b827c
Zampieri, F. G., Nassar, A. P. Jr., Gusmao-Flores, D., Taniguchi, L. U., Torres, A., and Ranzani, O. T. (2015). Nebulized antibiotics for ventilator-associated pneumonia: a systematic review and meta-analysis. Crit. Care 19:150. doi: 10. 1186/s13054-015-0868-y

Zand, F., Zahed, L., Mansouri, P., Dehghanrad, F., Bahrani, M., and Ghorbani, M. (2017). The effects of oral rinse with $0.2 \%$ and $2 \%$ chlorhexidine on oropharyngeal colonization and ventilator associated pneumonia in adults' intensive care units. J. Crit. Care 40, 318-322. doi: 10.1016/j.jcrc.2017. 02.029

Conflict of Interest Statement: The authors declare that the research was conducted in the absence of any commercial or financial relationships that could be construed as a potential conflict of interest.

Copyright (C) 2019 Xie, Lyu, Hussain and Li. This is an open-access article distributed under the terms of the Creative Commons Attribution License (CC BY). The use, distribution or reproduction in other forums is permitted, provided the original author(s) and the copyright owner(s) are credited and that the original publication in this journal is cited, in accordance with accepted academic practice. No use, distribution or reproduction is permitted which does not comply with these terms. 